\title{
Reading race: The curriculum as a site of transformation
}

\author{
H-J. Esakov \\ University of Pretoria \\ South Africa \\ e-mail: esakov.hi@gmail.com
}

\begin{abstract}
This article looks at social transformation at a former whites-only Afrikaans university from beyond the conventional focus of demographic reform. Rather, in using a qualitative case study, it broadly explores how transformation of higher education institutions can be read in terms of the re-imaging of racial identity within the curriculum. In looking at how an institution navigates social transformation through its positioning of the role of the curriculum in the transformation process, this article suggests that although rhetorically committed to transformation, the university is struggling to emerge from its own politically instrumentalist past. Further, findings show that pressure exerted on the university from government and grassroots level within the university, are impeding the transformation process.
\end{abstract}

\section{INTRODUCTION}

Transformation of higher education institutions is a messy business. The widelypublicised Mamdani and Makgoba affairs, the Prof. Benatar 'debate' and the racist and incendiary 'Reitz-residence' video, not only attest to this, but have shown transformation to be a deeply emotional, contentious and complex matter. This article draws from research conducted for my master's study that examines one such transformation struggle - although this struggle has not been generally recognised as such, even within the university at which it took place. The study touched on a number of thorny issues in higher education. Firstly, it looked at a struggle surrounding how racial identity is being re-imagined within the curriculum. Secondly, it sought to explore what this struggle says about institutional ideologies and commitments to change.

\section{METHODOLOGY AND BACKGROUND TO THE ARTICLE}

My study looked at transformation from beyond the conventional focus on examining demographic change. Rather, in employing a qualitative case study approach and leaning on Michel Foucault's archaeological methodology (Deacon2003), Iexcavated, de-layered and probed at an inter-faculty contest over curriculum transformation at a former Whites-only Afrikaans university. ${ }^{1}$ Ostensibly, the controversy that ensued 
from this contest was over the contents of a module - the Ubuntu Module - taught in both the Faculty of Education and the Faculty of Humanities. On assessment of the module, the Faculty of Education deemed it to be 'profoundly racist'. ${ }^{2}$ Yet, adopting an antithetical stance, the Faculty of Humanities countered that it was 'certainly relevant and not outdated'. ${ }^{3}$ The module was abruptly withdrawn from the Faculty of Education's curriculum and the Head of the Faculty of Education also attempted to have it removed from the syllabus at the Faculty of Humanities. However, opposing the decision taken by the Faculty of Education, the Faculty of Humanities continues to offer the module.

The purpose of this article is not to elucidate on the actual contest surrounding the Ubuntu Module. Rather, it uses this transformation struggle as a point of departure to look at how the institution navigates social transformation through its positioning of the role of the curriculum in the transformation process. Indeed, as this article shows, the controversy goes beyond a dispute over a singular module, but offers a lens into an institutional stand towards readings of and commitments to qualitative and sustainable transformation. To expound on this, this article draws on the following selection of data used in my study:

- Semi-structured interviews conducted with two senior managers at the university - a senior member of management of the university (herein referred to as Prof. A) and the Head of the Faculty of Education (herein referred to as Prof. B). It also draws from interviews with the lecturer from the Faculty of Humanities who wrote and presents the Ubuntu Module (herein referred to as Mrs. C).

- Documents analysed include the university's policies and institutional text-based sources that specifically refer to or imply transformation.

In order to facilitate understanding of the broader implications of this struggle on how the university frames and broaches curriculum transformation, the debate needs to be contextualised and located within the historicity of South African race ontologies and epistemologies. Further, a brief exploration of the role that higher educational institutions have played in producing, sustaining and challenging race discourses through official knowledge, here, as via the curriculum, is necessitated. These are called for in order to mediate an understanding on how the curriculum as a reflector of broader society (Apple 2004), is fundamentally racialised (Goldberg 1996). These also serve to underscore the necessity for universities in a post-apartheid South Africa to critically engage with the type of knowledge structures that are often used to maintain the status quo.

\section{SOUTH AFRICA'S LEGACY OF RACE}

Mass social engineering, an integral feature of colonial rule (Mamdani 1997) in South Africa, sought to do more than physically segregate South African society along the racist constructs of White, Indian, Coloured and African. As Stephen 
Biko (2004) and other scholars of colonialism like Frantz Fanon (1986) and Ann Laura Stoler (1995) have pointed out, racial segregation's principal objective was to colonise the mind into accepting such hierarchical constructs as pre-ordained truths. Legislative as well as informal structurings of race experienced globally (Goldberg 1996) and in South Africa, most perceptibly during apartheid, aimed to normalise and naturalise race (Roos 2005; Zegeye 2001). These capillaries of structural racism intended to inure South Africans into accepting ontological framings and epistemological understandings of race as unquestioned 'truths'. As such, South Africans were 'taught' to identify and socialise within broad racial categories and 'their' ethnic subdivisions, with racialised identities being officially constructed as unalterable historical, ethnographic and cultural truths. Moreover, reified by the ideological myths of apartheid and scientific racism (Dubow 1995), race became a primary socio-economic divider.

\section{EDUCATION AND RACE: REIFICATION AND RESISTANCE}

In comprehending the extent to which hegemonic ideologies have been inscribed into the everyday practices and discourses of South Africans, it is important to read education as not confined merely to traditional domains such as schools and universities. Rather, from a Foucaultian perspective, under apartheid, state controlled education extended well beyond formal schooling (Deacon 2003, 2005). Thus, going beyond the immediate and formal aims of curricula, 'education' could be observed in the very structures of state and civil society. Through these capillaries of power, knowledge production and reproduction were further regulated and controlled by the state (Deacon 2005). Because of this, state and civil structures instilled practices of structural and institutionalised racism into everyday particularities (Goldberg 1996).

\section{UNIVERSITIES AS CAPILLARIES OF POWER}

Central to the reading of this article is the role of formal sites of education in structuring the normalisation and naturalisation of racialised identities. As John Comaroff maintains, from the advent of colonial rule up until the dismantling of legislative apartheid, 'invasive [pedagogical] technologies of mind and body was a crucial vector in the effort to insinuate new signs and practices amongst colonized peoples' $(2001,50)$. This was particularly so under the apartheid regime, where racisms were further rooted into the everyday actions of South Africans through schemes of official legitimization (Ashforth 1990) - or educational institutions - and scholarly discourses on racial superiority (Coetzee 1991; Dubow 1995). Universities were posited by the apartheid state as integral structural agents in the organisation and justification of apartheid's logic and they served as key locales where racial and cultural difference could be academically validated (Badat 1999; Coetzee 1991; Reddy 20044). The epistemological foundations of universities were deeply influenced by the prevailing normative ontologies of racial identity (Badat 2004; Jansen 1998; Mamdani 1997) 
- which were reciprocally influenced by formal academic epistemologies (Deacon 2005). Under the apartheid state, the establishment of universities in South Africa essentially mirrored apartheid's racial and ethnic divide.

Yet, different institutional contexts commonly reflected dramatically disparate and oppositional ideologies. The positioning of universities as structures of civil society may have been intended to serve state ideology in its implications of neutrality, but that very positioning opened the ideological boundaries of universities up to contestations and resistance (Reddy 2004). This resulted in the emergence of counter-hegemonic discourses amongst progressive intellectuals and students, mainly at historically black and historically white English-speaking institutions. This saw both the production (and reproduction) of normative racial identities, and counter-hegemonic identity contestations, often within a singular institution. However, historically white Afrikaans institutions were overtly supportive of the apartheid state.

\section{POST-APARTHEID IMPERATIVES}

In light of the significance of education in the structuring of South Africans' everyday lives, interrogating the role that formal education has played - and is playing - in the reproduction or challenging of identity articulations and understandings is crucial in South Africa's attempt to construct a society based on actualised human rights. Despite the role of universities in elaborating, nurturing and normalising racial identities, universities can, and do, play a significant role in redress and social transformation as 'humankind sees in education an indispensable asset in its attempt to attain the ideals of peace, freedom and social justice' (Delors 1996, 12). Yet, as an area of critical research, the role of universities' curricula in critical readings of the social transformation enterprise - and particularly how universities position their commitment to social transformation, as read via their approach to curriculum transformation, has been virtually overlooked. Thus this article underscores that readings of institutional stands towards curriculum transformation can offer a lens into understandings of broader institutional and, indeed, social transformation.

\section{THE INSTITUTIONAL SETTING: THE RHETORIC OF TRANSFORMATION}

This article shows that governmental policies have had both a direct and an indirect influence on institutional positionings on race and attendant transformation initiatives. With a focus on redress, post-apartheid South Africa heralded an array of official policies seeking and legislating attempts at social transformation. From the South African constitution to policies written specifically for higher education (Department of Education 19975, Republic of South Africa 1996'), institutions have been officially tasked with operationalising the social transformation policies set out. From its mission and vision statements to policies and strategic plans, the university 
under study has responded to these commissions on an official, institutional level, asserting a commitment to '[the] promotion of equity, access, equal opportunities, redress, transformation and diversity' (University of 2007a, online). ${ }^{7}$ However, although this article acknowledges the centrality and importance of these policies, plans and statements in the transformation process, what it seeks to do is to go beyond the semantics, and explore how these initiatives are being operationalised. It asserts that unless there is significant and meaningful implementation, particularly in terms of curriculum content, plans and policies are but hollow rhetoric, and 'at best political symbols' (Jansen 1998, 106).

\section{TRANSFORMATION? INSTITUTIONAL IDEOLOGIES AND INDIVIDUAL INTERPRETATIONS}

This article subscribes to Michael Apple's (2004) positioning of the curriculum as a reflector of broader social histories and contradictions, a reflector of change or conservatism. It also underscores that connotations of power inequities remain an integral part of understandings and discourses of racial identity. Therefore, of significance in reading institutional positionings to transformation is exploring how transformation is playing out in terms of the extent to which 'the reproduction [and challenging] of particular identities ... is grounded in' (Mamdani 1997, 153) not only institutional ideologies, but also curriculum content. Further, how policies, plans and statements filter down from governmental to institutional policy, and then to the role-players who ultimately enact them, is central to reading the trajectory and pace of transformation at an institution. As a corollary, I would assert that personal understandings of race will, and do, impinge on how transformation is thought about and implemented, as ultimately, personal understandings are deeply entwined with institutional readings and articulations on race.

The university has a history as a bastion of Afrikanerdom and white privilege, and in many quarters, understandings of race as a homogenised essential truth continue to prevail in it. Thus, it is perhaps unsurprising that there is significant resistance to transformation from many staff members, particularly in view of the perception that transformation is associated with the dismantling of white privilege. Reflecting on prevalent attitudes which inform personal readings, and thus the implementations of transformation, Prof. B commented: 'there are a whole lot of people here who still believe that black people are somehow less capable than white people. Trust me on that one' (interview with Prof. B, Head of the Faculty of Education 2007). This seemingly stubborn residual of a longitudinal structuring of race on the basis of perceived ability, or what Prof. A alluded to as the superiority/inferiority binary, was corroborated by Prof. A as a significant challenge to transformation:

There is much room for the university community to move away from stereotyping and what was associated with the construction of race within the previous dispensation. And I think that is slowly developing, we have pockets at the university where I 
think that people have crossed those sort of obstacles. There are other pockets at the university where we are not near that (interview with Prof. A, a senior member of management 2007).

As Prof. A suggests, it is necessary to acknowledge that 'at the level of people' (interview with Prof. B 2007), attitudinal beliefs and actions belie, and resist, the rhetoric of redress. Consequently, there are significant obstacles to institutional attempts to implement directives of transformation. This will - and does - impede the transformation process, regardless of what is enacted in plans and policies. Of significance is that this has a direct impact on what is written and taught in the curriculum. This problem was particularly underscored by Prof. B, who shed a historicised light on this resistance to change:

Let me tell you why transformation at the level of people won't work. You are asking one of the most marginalised groups in the new political dispensation, the Afrikaners, to work against their own interests. What the hell! Do you think that was a reasonable thing to ask? You literally asking people to give up their own jobs, and to give up the jobs they would naturally and instinctively want to preserve for what they see as their own kind. You ask for them to give that up for people that for years they thought and were told were the threat. Who the hell are we fooling? It's counter-intuitive (interview with Prof. B, Head of the Faculty of Education 2007).

From Prof. B's commentary it can further be construed that at a previously white Afrikaans institution it is therefore fundamental for leadership not only to frame transformation, but also to play a decisive role in the implementation and guidance of transformation. However, according to Prof. B, as the conflict around the Ubuntu Module has suggested, the reason that struggles surrounding transformation abound should actually be understood in terms of a lack of political will at the level of leadership:

Well it's always much deeper, I mean what drags down the ship, if you want, is the fact that in the university as a whole there is - I mean I raised this issue with several members of the senior management at this university. Not a single one of them, as far as I know, have raised hell about this. So there are institutional forces which pull down much more powerfully this consensus around what knowledge is. So I know what we are up against. However, I am also convinced about the fact that these things only change at a faculty level where there is leadership that is determined to change (interview with Prof. B, Head of the Faculty of Education 2007).

\section{IS THE INSTITUTION 'DISCHARGENG [ITS] SOCIAL RESPONSIBILITIES'?8}

As this study attests, curricula are not written in a void, but are the product of conditions of struggle and consensus in the prevailing hegemonic order (Comaroff and Comaroff 1992). Thus, with race and power relations intrinsically interwoven 
readings of treatment of racial identity in the curriculum can be seen as a potent determinant in the analysis of both the power differentials and the dynamics informing the ontological and epistemological underpinnings of an institution. This is of particular relevance at a university which has its historical roots in the promulgation and propagation of racist thinking. Thus, fundamental to this article is a critical reading of how official directives are framed by the institution and subsequently implemented via the curriculum; that is, how is 'the university [as] a symbol of national aspiration and hope, reconciliation and pride ... discharging its social responsibilities'? (University of 2007a, online).

Examining documentation through the lens of a post-colonial hermeneutic: post-colonial archiving (Stoler 2002), and leaning on the Foucaultian analytic of discourse theory, I sought to analyse the 'official voice' of the institution as presented in these documents. The purpose was to explore these directives as epistemologies in themselves, and ask how 'meaning arises not from language but from institutional practices, from power relations' (Ball 1990, 2). In accordance with these critical analytics, it is necessary to explore not only what is said, but also that which is not said: the gaps, silences and the truncations. Thus, in looking at institutional frameworks, it was necessary to ask "why out of all possible things that could be said, only certain things were said: how is it that one particular statement appeared rather than another' (Foucault as cited in Ball 1990, 3).

\section{POLICY HINDRANCES OR INSTITUTIONAL INERTIA?}

As a point of departure, a critical examination of all official documentation with references to transformation was necessary in understanding how the university officially frames transformation. The focus would then be narrowed down to analyse how the university formally broaches, and subsequently implements, curriculum transformation. It transpired that although the university has a language policy, an employment equity plan, and a strategic plan with a section dedicated to transformation, there is no specific transformation policy.

With the strategic plan asserting that 'within universities, academic transformation should always be primary objective' (University of __ 2007b, online), ${ }^{9}$ I was perplexed by this noticeable omission. Why had a transformation policy not been drawn up? I posed the question to Prof. A, who explained the position taken by the university:

You would not find a single document dealing with transformation only. Our approach is that if you talk about transformation, you are actually talking about all the dimensions of the activities of the university .... What we also intended doing was to make sure that we extract from the strategic plan specifically the transformational issues, and put up a transformational agenda for the university, with accompanied strategies and timelines and so on. Now we haven't done that yet. We haven't interpreted our strategic plan to get to that point. But it is an absolutely necessary exercise for the university, and we hope to produce a document that would really be aligned with 
the strategic plan and strategies of the university (interview with Prof. A, a senior member of management 2007).

\section{LAISSEZ-FAIRE}

I would like to focus on two seemingly paradoxical points mentioned here. The first is the institution's approach to transformation. Prof. A suggests that the university recognises that transformation encompasses all aspects of university life, and that this is why there is no specific transformation policy. Secondly, he goes onto concede that the university intends to establish a transformation agenda interpreted from the strategic plan. However, he says, 'it is being decided upon, but we haven't done it so far' (interview with Prof. A 2007). I would argue that with the magnitude of transformation acknowledged, this position does not cohere with the university's seemingly laissez-faire response to transformation across the board. Surely, with transformation affecting 'all dimensions of the activities of the university' (interview with Prof. A 2007) this should either impel the university to expedite the transformation agenda, or necessitate the drawing up of a transformation policy?

In addition, the university's strategic plan claims that: 'the true meaning of transformation is much deeper and richer than the correction of demographic imbalances'(University of __2007b, online). This suggests that although quantitative or numerical transformation is of significance in the transformation process, real, meaningful transformation must be gauged on a more qualitative level. In turn, this is premised on a trenchant, critical and ethical argument against essentialised and naturalised ideas of race. This then raises the question: with the official voice articulating a multifaceted and, indeed, substantive reading of transformation which would go beyond mere head-counts, what aspects of operationalised transformation take pre-eminence at the university?

\section{THE FOCUS OF TRANSFORMATION}

During our discussion, Prof. A spoke of the more dominant areas in which the university had focused on transformation:

We addressed the language issue for instance, the whole issue of student governance, of participation and inclusivity that you need to have for successful student governance. We focused on transforming our residences, and residence life... . We have an employment equity plan, which is on the website of the university, spelling out targets, strategies and responsibilities and so forth. And we would also have institutional governance structures that would deal with that in a very specific way, like the employment equity forum. We have to report to the Department of Labour annually on the progress we are making against our targets. So the different dimensions which you would find within the university would dictate how pertinent you have a separate plan or not when it comes to transformation (interview with Prof. A, a senior member of management 2007). 
It could be suggested, as reflected in the above explanation by Prof. A, that the areas of focus that take pre-eminence in transformation are those in which the university has been under governmental scrutiny and has had to respond on a legislative level. Put crassly, quotas have become not only the yardstick by which to measure levels of transformation, but a primary focus of transformation. As this indicates, it appears that the reality of transformation belies the rhetoric of a university committed to meaningful, qualitative change.

\section{'WE CAN ONLY DECONSTRUCT RACE AS FAR AS WE ARE AFFORDED THE SPACE DO THAT'10}

Although not appearing to deflect responsibility from the institution Prof. A implied that official governmental initiatives, with the directive for universities to use race categories, are doing more to hamper qualitative transformation than promote to it. Prof. A discussed the difficulty that this has subsequently posed for the university: 'You know, we can only deconstruct race as far as we are afforded the space to do that. I think that the space is limited when it comes to the legal frameworks imposed on the university from the paradigm of deconstructing race' (interview with Prof. A 2007). The confusion caused by uncritically employing race categories, or racial classifications reflecting and echoing apartheid's categories, that the university is legislatively obliged to use, arguably serves to not only limit transformation, but avert the focus of power relations and dynamics embedded within these racial categories. Indeed, in presenting races as fundaments in discourses of redress, by ignoring the inherent and complex dynamism and power differentials infused in these categories, they are but re-inscribed as normative.

Further, it emerged that this type of quantitative, unproblematic focus on race is having a direct impact on how race is being articulated in the curriculum. This can be read in the following comment from Mrs. C, the course-writer and lecturer for the Ubuntu Module: 'Only to hear that I shouldn't say black or white [in the Ubuntu Module]. Now how do I go about it? Then you get to the university itself, go and look at their admission. It still has Black, Asian and Coloured and so on' (interview with Mrs. C 2007). As this comment suggests, it can indeed be retrogressive to focus the implementation of transformation on demographic reform. In essentially adhering to a governmental focus on performance indicators, it serves to over-determine racial identities and re-reify identities of old. Indeed, as Jonathan Jansen concurs, a myopic focus on indices 'signals little of the depth, quality and sustainability of transformation given the fixation of this approach with numerical indices of performance such as the 'number of African students enrolled' without inquiring, for example, about the nature of the curriculum experience' $(1998,106)$.

Although the need for racial redress is unarguably an imperative in the statedriven transformation process, in focusing redress primarily on race as structured by political identities, apartheid categories are being not only revisited, but also revitalised. At an institution that has historical links to the academic validation of 
apartheid identities, this is acutely problematic. Indeed, not only are perverted notions of racial identity being reproduced in the university, but areas of critical importance, such as the curriculum, that can be seen as reflectors of meaningful transformation, also remain, intentionally or unintentionally, undiagnosed. This concern was voiced by Prof. B, who gave his view of this obstacle to transformation:

There is an inertia, there is a knowledge, an epistemological inertia, definitely that is used to slow down the transformation, once you get beyond the black faces and the female faces and so on, which are important issues. Getting down to the curriculum foundations, you know, it's not that easy to change over to what people tell you; it's not easy (interview with Prof. B, Head of the Faculty of Education 2007).

The above commentary suggests that, if left up to the individual actors, transformation will be decelerated. This further underscores the imperative of institutional leadership in transformation. Thus it is particularly problematic that curriculum transformation is merely alluded to in the strategic plan. However, with pressures from both above (in the governmental focus on quotas), and below (in resistance from both staff and students who are attempting to safeguard power and privilege associated with their whiteness), the university has found itself in a tenuous position which can best be viewed as strategic compromise. This has seen curriculum transformation being perceptibly overlooked.

\section{CURRICULUM TRANSFORMATION: GOING BELOW THE RADAR}

Indeed, the most substantive reference to curriculum transformation can be read in the dictum 'academic transformation should always be primary objective' (University of $2007 \mathrm{~b}$, online). This oversight can be seen as a casualty of governmental pressure on the university to meet the indices set out for it. However, a more polemical reading could be, as suggested by Prof. B, that the oversight is based on a sense of selfpreservation and, thus, an intentional sidestepping of curriculum transformation:

Think of the curriculum as the institution and you begin to understand why it doesn't change by dictate or by pronouncement, because it is interwoven with the barriers and belief systems of the institution. The institutional curriculum, as is the place everywhere, serves preservation - it preserves rather than transforms. The fact that there is a particularly innovative curriculum under some professors obviously is important as part of what I call the chipping away of certainty in the belief system. But the institutional curriculum is so large, so powerful, that it overshadows (interview with Prof. B 2007).

As Prof. A conceded, the university is afforded space to manoeuvre in the transformation enterprise. Yet, with the university seeming to focus its transformation primarily on areas where it is under official scrutiny, this has allowed for more nuanced transformation responsibilities, such as transformation of curriculum content, to fall 
below the radar. Indeed, Prof. A candidly acknowledged that the university has fallen short with regard to curriculum transformation:

It only came later, the view of transforming curriculum, and I'm not so sure that we have made the progress with regard to that, or that we have created the sensitivity with regard to that you would expect of an institution of this kind. So, I think that there is room to deconstruct race within the core business of the university, but we are talking about a very sophisticated conceptual framework that you have to understand to be able to isolate yourself from the statutory frameworks imposed on the university, and what is left for the university community with regard to the core function of the university, and I think that in little space that we have, which should be dominant space at the university, there is much room for the university community to move away from stereotyping and what was associated with the construction of race within the previous dispensation (interview with Prof. A, a senior member of management, 2007).

However, it must be kept in mind that when speaking of curriculum transformation it is important to differentiate between routine change and more nuanced, qualitative revisions and updates in the curriculum that strike at the foundation of the epistemological edifice. The curriculum is never a static entity, and is constantly open to change. Prof. A explained that although curriculum revision is routine at the institution, for the most part, change of curriculum content has overlooked the crucial area of the re-imagining of racial identities in post-apartheid South Africa:

If you talk about curriculum transformation within the context of the obvious context which is given to transformation in this country, changing the curriculum, adding to it, revising it, you know, that is standard procedure at the university. And if you unpack the agenda of the senate at the university, which has got the obvious mandate to look at the academic enterprise of the university, you would find in each and every agenda of senate quite a lot of proposals pertaining to the change of curriculum. But, those changes were not exclusively, or in a very important way, focused on the changing context in South Africa with a specific focus on transformation, against the backdrop of the changes which took place in South Africa as part of the political changes and so forth (interview with Prof. A 2007, a senior member of management).

In a country with a history in which education has played a fundamental role in the structuring of racialised selves, and at a university with a history of academically reifying (or producing) and reproducing these identities, this can be viewed as a blatant oversight. Indeed, reflecting on the importance and even the responsibility that education and a university have in broader social transformation and redress, Prof. B commented:

Well I think in the context of South Africa the role of education is to give people a new language through which they can envisage themselves. I think at the moment we are caught in a linguistic trap, in that the only way we can speak to each other is through 
boxes: through boxes of African, Coloured, Indian, White. Those boxed identities are reinforced daily through bureaucratic forms to fill out; census, the employment equity, they become so real to how people see the world that those categories do enormous damage. The question I pose is what kind of pedagogy can enable us to think differently about ourselves and therefore about others. That for me is the single most important challenge (interview with Prof. B, Head of the Faculty of Education 2007).

As Prof. B suggests, in uncritically following governmental policies, universities are doing more to re-inscribe and revitalise racist categories and knowledges than they are to promote and '[encourage] critical questioning' (University of __ 2007b, online). The contentions and struggles surrounding revisionism and transformation became acutely apparent during my interview with Prof. B. His disillusion with the levels of transformation at the university was palpable in his pejorative commentary on what he saw as the university's unchanged epistemological foundations:

This place, which is tied up in a medieval epistemology and politics that is so scary that you wonder whether this university can serve any kind of totalitarian regime, reflexively, because of its inability to question, its inability to take a moral stance, on anything except as a reflexive kind, a servile kind of response to authority - any authority (interview with Prof. B, Head of the Faculty of Education 2007).

\section{CONCLUSION}

As Prof. B implies, if the dynamics of power in knowledge production are not critically analysed and deconstructed, and curriculum content continues to reflect ideologies of old, not only is the university's role as a critical voice of society undermined, but the university can be seen as the antithesis of the defender of democratic values, and rather as a lackey to authority - 'any authority' (interview with Prof. B 2007). What is of significance in this observation is Prof. B's allusion to an institution governed by an ontology seeped in a conservatism that continues to reproduce an epistemology still reflecting a fundamentally essentialised view on race. However, I would suggest that any understandings of the university's approach to transformation must be read in terms of sociohistorical context of the institution. This requires a cognisance of an institutional ethos which has been mired by apartheid discourses and knowledges knowledges which were presented as indisputable canonical truths. This helps render an understanding of why attitudes, beliefs and, by extension, epistemologies 'do not change by dictate' (interview with Prof. B 2007) (that being, policies, plans and broader pronouncements). Although this article does not attempt to exonerate the university with regard to its responsibilities, it suggests that institutions are facing enormous pressures in the transformation process; pressures being exerted on the university from both above (governmental directives) and below (attitudes, beliefs and grassroots reactions of students and staff). Is it thus surprising that transformation struggles continue to beset higher educational institutions? 


\section{ENDNOTES}

1 Due to ethical considerations, the institution as well as the participants will remain anonymous. To ensure this, anonymity is also maintained in all referencing of the university.

2 Interview with Head of the Faculty of Education.

3 Interview with a senior member of the Faculty of Humanities and the department in which the Ubuntu Module is presented and from which it is outsourced.

4 Reddy, T. 2004. Higher education and social transformation: A South African case study. Available at: http://download.che.ac.za/documents/d000066/HEandSocialTransf ormationReport_25Feb2004.pdf. Accessed on 22 March 2008.

5 Department of Education. 1997. Education White Paper 3: A Programme for the transformation of higher education. Available at: http://www.info.gov.za/whitepapers/1997/ educ3.pdf. Accessed on 1 January 2008.

6 Republic of South Africa. 1996. Constitution of the Republic of South Africa. Available at: http://www.info.gov.za/documents/constitution/1996/a108-96.pdf. Accessed on 1 October 2007.

7 University of __. 2007a. Mission and vision. Online. Accessed on 22 August 2007.

8 University of __. 2007a, online.

9 University of __. 2007b. The strategic plan of the university of __. Online. Accessed on 22 August 2007.

10 Interview with Prof. A.

\section{REFERENCES}

Apple, M. W. 2004. Ideology and curriculum. Third edition. New York: RoutledgeFalmer.

Ashforth, A. 1990. The politics of official discourse in twentieth-century South Africa. Oxford: Clarendon Press.

Ball, S. J. 1990. Introducing Monsieur Foucault. In Foucault and education: Discipline and knowledge, ed. S. J. Ball. London: Routledge.

Badat, S. 1999. Black student politics, higher education and apartheid: From SASO to SANSCO, 1968-1990. Pretoria: HSRC.

Biko, S. 2004. I write what I like. First published in 1978. Johannesburg: Picador Africa.

Coetzee, J. M. 1991. The mind of apartheid: Geoffrey Cronjé (1907- ). Social Dynamics 17 (1): $1-35$.

Comaroff, J. and J. Comaroff. 1992. Studies in the ethnographic imagination. Boulder: Westview Press.

Comaroff, J. 2001. Reflections on the colonial state, in South Africa and elsewhere: Factions, fragments, facts and fictions. In Social identities in the new South Africa: After apartheid. Volume 1, ed. A. Zegeye, 37-80. Cape Town: Kwela.

Deacon, R. 2003. Fabricating Foucault: Rationalising the management of individuals. Milwaukee: Marquette University Press.

- 2005. Capacity-communication-power: Foucault on contemporary education. Perspectives in Education 23 (2): 73-83.

Delors, J. 1996. Learning: the treasure within. Report to UNESCO of the international Commission on Education for the Twenty-first Century. Paris: UNESCO.

Dubow, S. 1995. Illicit union: Scientific racism in modern South Africa. Johannesburg: Witwatersrand University Press. 
Fanon, F. 1986. Black skin, white masks. First published in 1967. London: Pluto Press.

Goldberg, D. 1996. Racist culture: Philosophy and the politics of meaning. Massachusetts: Blackwell.

Jansen, J. D. 1998. But our natives are different! Race, knowledge and power in the academy. Social Dynamics 24 (2): 106-116.

Mamdani, M. 1997. Africa and African Studies. In Knowledge, identity and curriculum transformation in Africa, eds. N. Cloete, J. Muller, M. W. Makgoba and D. Ekong, 149-154. Cape Town: Maskew, Miller and Longman.

Roos, N. 2005. Ordinary Springboks: White servicemen and social justice in South Africa, 1939-1961. Aldershot: Ashgate.

Stoler, A. L. 1995. Race and the education of desire: Foucault's history of sexuality and the colonial order of things. Durham: Duke University Press.

Stoler, A. L. 2002. Colonial archives and the arts of governance. Archival Science (2):87-109.

Zegeye, A. 2001. Imposed ethnicity. In Social identities in the new South Africa: After apartheid. Volume 1, ed. A. Zegeye, 1-23. Cape Town: Kwela. 